method in 11 women; in 13 subjects who claim they used the method correctly apparently the method failed.

The method is well tolerated and accepted by subjects who had experienced previous intolerance to conventional oral combined or sequential therapy. Its low cost and ease of administration makes it of interest to developing countries with limited resources for family planning.

This work was supported in part by a grant from the Ford Foundation to the University Maternity Hospital, University of Chile Medical School, for the "University Programme for Research and Training in Reproductive Biology and Human Fertility Control."

We are indebted to Syntex Laboratories Inc., Palo Alto, California (U.S.A.), and E. Merck-Darmstadt (Germany) for the generous supply of chiormadinone 0.5 -mg. tablets.

Requests for reprints should be addressed to Dr. J. Zañartu, Departamento de Fertilidad, Casilla 6637, Santiago, Chile.

\section{REFERENCES}

Gomez-Rogers, C., Ibarra, A., and Guiloff, E. (1967). Report to VIII World I.P.P.F. Congress (Santiago, Chile), April.
Martinez-Manautou, J., Giner-Velazques, J., Cortes-Gallegos, V., Casasola, J., Aznar, R., and Rudel, H. W. (1965). Excerpta Medica International Congress Series, 112, 157.

Martinez-Manautou, J., Cortez, V., Giner, J., Aznar, R., Casasola, J., and Rudel, H. W. (1966). Fret. Steril., 17, 49.

Martinez-Manautou, J., et al. (1967a). Brit. med. f., 2, 730.

Martinez-Manautou, J., Giner, J., Aznar, R., Lozano, M., and Rudel, H. W. (1967b). Report to VIII World Congress I.P.P.F. (Santiago, Chile), April

Orellana-Alcalde, J. M., and Dominguez, J. P. (1966). Lancet, 2, 1278.

Orellana-Alcalde, J. M., and Dominguez, J. P. (1968). Personal communication. To be reported.

Pincus, G., Rock, J., and Garcia, C. R. (1958). Ann. N.Y. Acad. Sci.,

Rosenberg, D., and Zañartu, J. (1967). Rev. méd. Chile, 95, 501.

Rudel, H. W., Martinez-Manautou, J., and Maqueo-Topete, M. (1965) Fert. Steril., 16, 158.

Rudel, H. W., and Kincl, F. A. (1966). Acta endocr. (Kbh.), Suppl. No. $105,51,7$.

Sulimovici, 'S., Lunenfeld, B., and Shelesnyak, M. C. (1965). Acta endocr. (Kbh.), 49, 97.

Zañartu, J. (1964). Int. F. Fert., 9, 225.

Zañartu, J. (1967). Excerpta Medica International Congress Series, 133, 704.

Zañartu, J. and Navarro, C. (1965). Excerpta Medica International Congress Series, 112, 150 .

Zañartı,, J., Rosenberg, D., and Puga, J. (1965). Report to VI Pan American Congress of Endocrinology, Mexico City, October.

Zañartu, J., Pupkin, M., Rosenberg, D., Puga, J. A., and Guerrero, R. (1967). Rev. méd. Chile, 95, 512 .

\title{
Effect of Oral Continuous Progestogen Therapy in Microdosage on Human Ovary and Sperm Transport
}

\author{
JUAN ZAÑARTU, M.D. ; MARCOS PUPKIN, M.D. ; DAVID ROSENBERG, M.D. \\ RODOLFO GUERRERO, B.CH.; ROGELIO RODRIGUEZ-BRAVO, M.D. \\ MARCIAL GARCIA-HUIDOBRO, M.D. ; JUAN A. PUGA, M.D.
}

Brit. med. F., 1968, 2, 266-269

Therapy with oral continuous progestogens in microdosage is an effective and simple contraceptive steroidal method (Martinez-Manautou et al., 1965, 1966, 1967 ; Rudel et al., 1965). However, its mechanism of action has not yet been fully clarified. It has been claimed that ovulation is usually preserved, and eventually the main factors conditioning the contraceptive effect are the changes induced on the secretion of the cervical glands (Zañartu, 1964, 1967 ; Martinez-Manautou et al., 1966, 1967).

This paper attempts to throw further light on the possible antifertility mechanism of this method.

\section{Material and Methods}

Twelve young fertile women underwent surgical operation while receiving oral continuous chlormadinone acetate $0.5 \mathrm{mg}$. contraceptive therapy for 4 to 19 months. Their ages ranged from 32 to 39 years (Table I).

Before surgery the antioestrogenic effect of the compounds was evaluated by serial vaginal cytology, cervical mucus tests (its tolerance to sperm as seen 6 to 12 hours after coitus), and endometrial histology in the same and/or preceding cycle to the operation. Vaginal smears and Huhner-Sims post-coital tests were done between the $7 \mathrm{th}$ and $10 \mathrm{th}, 13 \mathrm{th}$ and $16 \mathrm{th}$, and 22nd and 26th days of the cycle. Endometrial tissue was obtained by biopsy around the 22nd to the 26th day (Noyes et al., 1950). The 24-hour urinary pregnanediol excretion was studied between the 8 th and 14th days and the $22 \mathrm{nd}$ and 26 th days on those subjects with regular cycles (Sulmovici et al., 1965).

Laparotomy was done on the 14th, 15th (four women), 16th, $17 \mathrm{th}, 19 \mathrm{th}, 21 \mathrm{st}, 26 \mathrm{th}$, and $27 \mathrm{th}$ days of the cycle and in one subject who was amenorrhoeic, the latter symptom persisting after lactation was discontinued. The object was tubal sterilization in 10 patients, and treatment of non-gynaecological conditions in two. Careful macroscopic examination of the uterus, Fallopian tubes, and both ovaries was carried out. Then a substantial wedge biopsy specimen was taken from an area of the gonad where there was definite evidence of some functional activity (mature follicle, cystic follicle, follicular cyst, corpus luteum, etc.). The ovarian tissue was processed for conventional haematoxylin-eosin and van Gieson staining methods in serial sections, as well as histochemical identification of carbohydrates and steroid-converting enzymes. For this purpose part of the biopsy specimen was immediately frozen and sectioned on a cryostat at $-20^{\circ} \mathrm{C}$., $16 \mu$, and incubated at $37^{\circ} \mathrm{C}$. Techniques were used for demonstration of lactic, succinic, glucose-6-phosphate, 3 - $\beta$-hydroxysteroid, and $20-\alpha$-hydroxysteroid dehydrogenases. Some ovarian sections were also stained with Sudan black for total lipids (Pupkin et al., 1966).

The appearance of both ovaries, particularly in respect of their size, aspect and number of cysts, signs of ovulation, and presence of corpora lutea, was carefully recorded. The germinal epithelium, ovarian cortex stroma, characteristics of follicles, cysts, with or without luteinization of the theca interna, were also studied histologically.

Follicles were classified as: "primary" (I), when the egg-cell was surrounded by a single layer of flat epithelium; "secondary" (II), if one or more stratified granulosa cell layers were present ; " tertiary" (III) or vcsicular follicles, with antrum and fluid; Graafian and "ruature" follicles, containing numerous layers of granulosa cells, a developed, eccentric

\footnotetext{
* Department of Fertility and Laboratory of Morpho-Physiology, University Maternity Hospital, University of Chile Medical School, Santiago, Chile.
} 
cumulus oophorus with ova and corona radiata. If a differentiated and luteinized theca interna existed, with abundant blood vessels, its presence was also recorded (Zañartu et al., 1965, 1967). The presence of cystic follicles (1 to $5 \mathrm{~mm}$. diameter) or follicular cysts (up to $2.5 \mathrm{~cm}$.), with or without luteinization of the theca interna, was tabulated as well. We have regarded as "normal" an ovary containing up to 10 of these cysts. When a corpus luteum was present, its age was assessed histologically and correlated with the endometrial histology and urinary excretion of pregnanediol.

Careful evaluation of cortical stroma for fibrosis or fibrillar condensation (reticulum and collagen tissue) was carried out. The findings were compared with those from a non-treated ovulatory and fertile group of women within the same age range (Zañartu et al., 1967).

Finally, in 10 women surgery was performed 12 to 20 hours after coitus. One oviduct was immediately flushed with buffered physiological saline or Ringer-Locke solution, and the fluid and its centrifugate were examined for the presence of spermatozoa.

\section{Results}

Since these women were young, and were known to be fertile, we may presume that they had ovulatory cycles before the contraceptive therapy was started (with the exception of three subjects in whom it was started while they were lactating and amenorrhoeic).

The results of investigations on cervical mucus, endometrial histology, and urinary pregnanediol levels carried out before surgery are summarized in Table I. At the time of operation the subjects had been receiving therapy for 4 to 19 months. None was lactating. The length of the menstrual cycles showed wide variation. The amount of cervical mucus 6 to 12 hours after coitus and around the theoretical ovulation date showed considerable fluctuation, but ferning was usually negative or had a non-typical crystallization pattern. From 50 to $100 \%$ of the sperms seen were non-motile. However, some progressive active motility was observed in one patient (Case 10, 50\% motility), and $25 \%$ of sperms showed non-progressive motility in four women.

In five women the endometrium presented a histological pattern corresponding to the date of the cycle on which the biopsy was taken; in all the remaining women, however, there was a variable but definite antioestrogenic effect, particularly in the glandular epithelium.

The results of studies on ovarian morphology and the recovery of spermatozoa from the Fallopian tubes are given in Table II.

For proper evaluation of these observations it should be borne in mind that a macroscopic examination of both ovaries was

TABLE I.-Details of Cases

\begin{tabular}{|c|c|c|c|c|c|c|c|c|c|c|c|c|c|c|}
\hline \multirow[b]{2}{*}{$\begin{array}{l}\text { Case } \\
\text { Na. }\end{array}$} & \multirow[b]{2}{*}{ Ase } & \multirow[b]{2}{*}{ Pariky" } & \multirow{2}{*}{$\begin{array}{l}\text { Duration } \\
\text { of } \\
\text { Therapy } \\
\text { (Months) }\end{array}$} & \multirow{2}{*}{$\begin{array}{c}\text { Duration } \\
\text { of } \\
\text { Cyclest } \\
\text { (Days) }\end{array}$} & \multicolumn{4}{|c|}{ Mucus } & \multicolumn{2}{|c|}{ Endometrium } & \multicolumn{4}{|c|}{ Pregnanediol (mg/24 hrs.) } \\
\hline & & & & & $\begin{array}{c}\text { Day } \\
\text { of } \\
\text { Cycle }\end{array}$ & Amount & Cryst. S & $\begin{array}{l}\text { Sperms. } \\
\% \text { Non- } \\
\text { motilell }\end{array}$ & $\begin{array}{c}\text { Day } \\
\text { of } \\
\text { Cycle }\end{array}$ & Histology & $\begin{array}{c}\text { Day } \\
\text { of } \\
\text { Cycle }\end{array}$ & mg. & $\begin{array}{c}\text { Day } \\
\text { of } \\
\text { Cycle }\end{array}$ & mg. \\
\hline
\end{tabular}

\begin{tabular}{l|l|r|r|r|}
1 & 35 & $14-6-8$ & 7 & $12-47$ \\
2 & 34 & $7-0-7$ & 4 & $35-40$ \\
3 & 39 & $8-0-5$ & 19 & $12-75$ \\
4 & 35 & $15-5-7$ & 19 & $10-41$ \\
5 & 36 & $11-5-5$ & 9 & Am-23 \\
6 & 34 & $12-2-8$ & 10 & $15-42$
\end{tabular}

\begin{tabular}{l|c}
12 & + \\
12 & ++ \\
15 & +++ \\
16 & + \\
15 & + \\
18 & ++
\end{tabular}

Patients with Ovulation

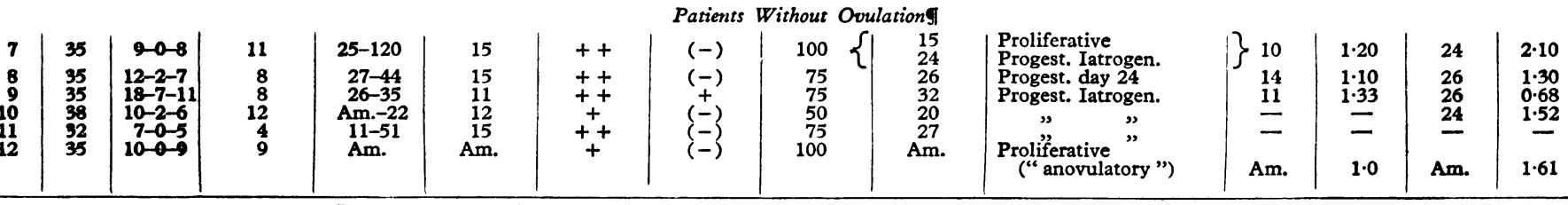

Progest. $=$ Progestational (secretory endometrium). Iatrogen $=$ Atypical, iatrogenic endometrium

$(-) \quad 100 \quad 11$

$(-)$

$(-)$

$(-)$

100

75

100

100

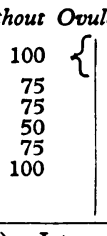

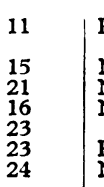

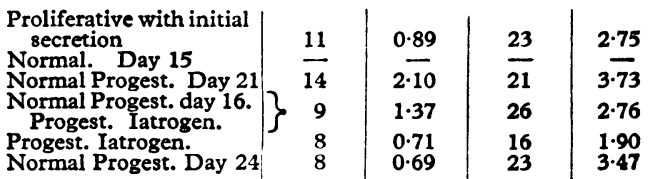

$1 \cdot 90$
$3 \cdot 47$

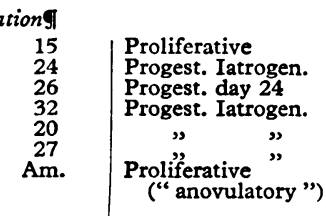

m.

ildren.

- First number indicates total number of pregnancies;
+ Shortest and longest cycles. Am. $=$ Amenorrhoea. † Amorant: + scanty; ++ moderate; +++ abundant. Frymt. = eryecallization; $(-)=$ megative ferning. Sperma: Percentage of non-motile spermatozoa. 91 When lapanotomy was performed.

Table II.-Ovaries and Fallopian Tube Findings. Patients with Ovulation

\begin{tabular}{|c|c|c|c|c|c|c|c|c|c|c|}
\hline \multirow{4}{*}{$\begin{array}{l}\text { Case } \\
\text { No. }\end{array}$} & \multirow{4}{*}{$\begin{array}{l}\text { Day of } \\
\text { Cycle }\end{array}$} & \multicolumn{8}{|c|}{ Ovaries } & \multirow{4}{*}{$\begin{array}{l}\text { Pallopian } \\
\text { Tubes } \\
\text { Flushing }\end{array}$} \\
\hline & & \multicolumn{2}{|c|}{ Macroscopy } & \multicolumn{6}{|c|}{ Histology } & \\
\hline & & \multirow{2}{*}{$\begin{array}{l}\text { Cysts } \\
\text { Follicular }\end{array}$} & \multirow{2}{*}{$\begin{array}{c}\text { Corpus } \\
\text { Luteum }\end{array}$} & \multicolumn{6}{|c|}{ Follicles* } & \\
\hline & & & & I & II & III & Graafian & $\begin{array}{c}\text { Mature } \\
\text { Ruptured }\end{array}$ & $\begin{array}{c}\text { Corpus } \\
\text { Luteum }\end{array}$ & \\
\hline \multicolumn{11}{|c|}{ Patients With Ovulation } \\
\hline $\begin{array}{l}1 \\
2 \\
3 \\
4 \\
5 \\
6\end{array}$ & $\begin{array}{l}14 \\
15 \\
15 \\
16 \\
17 \\
26\end{array}$ & $\begin{array}{l}+ \\
+ \\
+ \\
+ \\
0 \\
+\end{array}$ & $\begin{array}{c}0 \\
0 \\
0 \\
0 \\
0 \\
+\end{array}$ & $\begin{array}{l}+++ \\
+++ \\
++ \\
+ \\
++ \\
++\end{array}$ & $\begin{array}{l}++ \\
++ \\
++ \\
+ \\
++\end{array}$ & $\begin{array}{l}+ \\
0 \\
0 \\
+ \\
+ \\
+\end{array}$ & $\begin{array}{c}0 \\
0 \\
0 \\
+ \\
0 \\
0\end{array}$ & $\begin{array}{c}+ \\
0 \\
0 \\
0 \\
+ \\
0\end{array}$ & $\begin{array}{l}0 \\
+(I) \\
+(I) \\
+(I) \\
0 \\
+(I I I)\end{array}$ & $\begin{array}{l}\text { No sperms } \\
\text { No sperms } \\
\text { ", ", } \\
\text { " " }\end{array}$ \\
\hline
\end{tabular}

Follicles: $+++=$ numerous; $++=$ from 2 to 4 per section; $+=$ one; $0=$ none seen

+ Corpus luteum: (I) $=$ proliferative; (II) $=$ vascularized; (III) $=$ mature.
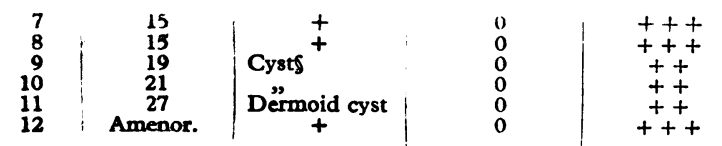

Patients Without Ovulation $\ddagger$
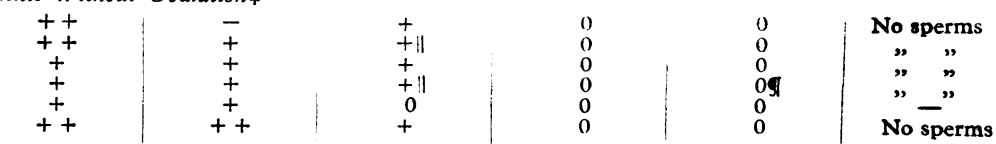

₹ When laparotomy was performed. $\$ 1$ to $2.5 \mathrm{~cm}$. in diameter. $\|$ With luteinized theca. I Corpis luteum in advan zed regression (from previous cycle?), 
done, but a section of only one gonad was available for histology and histochemistry. Hence if no corpus luteum was seen under these conditions it was possibly absent from the gonadal tissue left behind. On the other hand, the absence of corpus luteum on the day of the cycle in which the operation was performed does not imply that this subject would not ovulate at a later date-particularly if the study was done in the third week and there was a wide fluctuation in the length of the menstrual cycles.

Macroscopically the uterus and Fallopian tubes in these women were normal. The morphological findings in the oviduct will be reported elsewhere. Ovaries were also anatomically normal ; small cystic follicles, less than $0.5 \mathrm{~cm}$. in diameter, were usually present in one or both ovaries; larger follicular cysts were observed in Cases 9 and 10. One patient (Case 11) had a dermoid cyst, which clearly was not related to the contraceptive therapy.

The incidence of the main ovarian units seen in the histological study is summarized in Table II. It will be noted that there were from few to abundant primary and secondary follicles, and one to several "vesicular" follicles, while a Graafian follicle was usually found as well.

Ruptured mature follicles or a corpus luteum, or both, in a proliferative stage were present in five subjects; these should be regarded as signs of recent ovulation. In Case 6 there was a mature corpus luteum, with initial evidence of regression (Table II). On the other hand, in six women undergoing operation between the 15 th and the 27 th day no signs of ovulation were found. An old corpus luteum in advanced regression was found in Case 10 ; it was a regressive structure, possibly from a previous ovulatory cycle.

Our normal urinary 24-hour pregnanediol level in subjects who were having ovulatory cycles with an active corpus luteum found at operation has been over 1.5 to $2 \mathrm{mg}$. There was a positive correlation between the histological findings of a ruptured follicle or active corpus luteum and the pregnanediol excretion in five of the women studied (Tables I and II).

The enzymatic activity of dehydrogenases concerned in carbohydrate metabolism was found in all the ovarian morphological units with the exception of the corpus albicans. The highest activity was observed in the corpus luteum, theca interna of atretic follicles, and Graafian follicles. Mild to moderate enzymatic activity for $3-\beta$-hydroxysteroid dehydrogenase was present in the luteinized theca of Graafian and atretic follicles. In these conditions, no $20-\alpha$-hydroxysteroid dehydrogenase activity was found.

The presence of $20-\alpha$-hydroxysteroid dehydrogenase has considerable functional significance in dating the human corpus luteum. Our experience with this technique is still limited. The histochemical evaluation of 20 - $\alpha$-hydroxysteroid dehydrogenase in proliferative, mature, or regressive corpus luteum in these and other subjects treated with progestogens, as compared with a non-treated control group, will be reported later.

The search for sperms in the flushing fluid from the Fallopian tubes was negative. In fact, no spermatozoa were seen under microscopical examination of smears from the centrifugate or by direct examination of the fluid in 10 women ; in six the test was done on the 14 th to the 17 th day of the cycle. On the other hand, the same method applied in similar conditions in women who were using nylon intrauterine devices for contraception showed positive findings.

\section{Discussion}

Our findings confirm previous observations on the weak but evident antioestrogenic effect, with persistence of ovulation, in a significant number of women receiving oral continuous lowdosage contraceptive therapy with chlormadinone acetate.

Cervical mucous changes and hostility to spermatozoa are clearly shown in this study, but they are not fully consistent.
In a few observations motile sperms were seen. Nevertheless, no spermatozoa were found in the fluid recovered from washing the Fallopian tubes, so that it may be suggested that chlormadinone acetate prevented the ascent of spermatozoa.

The antifertility effect of the therapy was also evident at the endometrium level in most subjects.

The contraceptive progestogen does not modify the anatomy of the uterus, Fallopian tubes, and ovaries. No significant deviation from normal was observed by us. The incidence of follicular cysts was not higher than that found in normal subjects who are ovulating (Zañartu et al., 1965, 1967). Ovulation had evidently taken place in six women. Timing of surgery was too early for conclusions about anovulation in three subjects (Cases 10,11, and 12), but it seems reasonable to assume that it had not occurred in the cycle during which they underwent operation.

With the histological and histochemical methods used no definite morphological damage was observed in our material, though the duration of therapy was rather short for conclusions to be made.

It seems evident, therefore, that chlormadinone acetate in microdosage inhibits fertility by interfering at the levels of the cervical glands, endometrium, and, possibly, endosalpinx. Occasionally it also inhibits ovulation in certain more sensitive subjects. The presence of developing and Graafian follicles in these circumstances, as well as theca luteinization in atretic follicles, suggests that the gonadotropic effects of folliclestimulating hormone and the luteinizing hormone are not fully blocked. It might be expected that the use of a quantitative method of luteinizing hormone assay might provide important information in this context.

Some stromal fibrosis and increased atresia of follicles has been reported by Plate (1966) and Zussman et al. (1967) but not by Cremades et al. (1966), Ryan et al. (1964), and Maqueo and Goldzieher (1966) in ovaries from patients treated with " combined" oestrogen/progestogen contraceptive therapy. With the histological techniques used we have not observed definite hyperplasia or fibrosis of the ovarian cortical stroma or a significant disturbance of the atresic process. Nevertheless, it seemed evident that this therapy interfered with the control of ovarian function at least in some individuals.

\section{Summary}

Twelve young fertile women underwent surgical operation while under oral continuous chlormadinone acetate $0.5 \mathrm{mg}$. daily as contraceptive therapy. They had received the compound for 4 to 19 months.

Studies of cervical mucus, tolerance to sperms, endometrium histology, and urinary pregnanediol excretion before surgery demonstrated the existence of an antioestrogenic effect, while ovulation was preserved in some of these subjects.

Macroscopic examination of both ovaries and the histological study of ovarian tissue obtained by biopsy confirmed the presence of ovulation in six subjects. The timing of operation was not adequate for diagnosis of anovulation in two or possibly three subjects, but anovulation was evident in three women.

It is postulated that certain subjects are more sensitive to the progestogen in low dosage ; in such women prolonged menstrual cycles and anovulation are observed.

In 10 subjects no spermatozoa were found on flushing the oviduct from 12 to 20 hours after coitus.

Part of these studies were supported by a grant from the Ford Foundation to the University Maternity Hospital, University of Chile Medical School.

Chlormadinone acetate was generously donated by Syntex International (Mexico) and E. Merck-Darmstadt (Germany).

Requests for reprints should be addressed to Dr. J. Zañartu, Departamento de Fertilidad, Casilla 6637, Santiago, Chile. 
REFERENCES

Cremades, J. A., Sanchez de Ribera, G., and Botella-Llusia, J. (1966).

Acta Ginec., 17, 167.
Martinez-Manautou, J., Giner-Velazquez, J., Cortes-Gallegos, V., Casasola, J., Aznar, R., and Rudel, H. W. (1965). Excerpta Medica International Congress Series, 112, 157.

Martinez-Manautou, J., Cortez, V., Giner, J., Aznar, R., Casasola, J., and Rudel, H. W.' (1966). Fert. Steril., 17, 49.

Martinez-Manautou, J., et al. (1967). Brit. med. F., 2, 730.

Maqueo, M., and Goldzieher, J. M. (1966). Fert. Steril., 17, 676

Noyes, R. W., Hertig, A.' T., and Rock, J. (1950). Fert. Steril., 1,3 .

Plate, W. P. (1966). Acta endocr. (Kbh.), 55, 71.

Pupkin, M., Bratt, H., Weisz, J., Lloyd, C. W., and Balogh, K. (1966). Endocrinology, 79, 316.
Rudel, H. W., Martinez-Manautou, J., and Maqueo-Topete, M. (1965). Fert. Steril., 16, 158.

Ryan, G. M., Craig, J., and Reid, D. E. (1964). Amer. 7. Obstet., 90, 715 .

Sulimovici, S., Lunenfeld, B., and Shelesnyak, M. C. (1965). Acta endocr. (Kbh.), 49, 97.

Zañartu, J. (1964). Int. F. Fert., 9, 225.

Zañartu, J. (1967). Excerpta Medica International Congress Series, 133, 704.

Zañartu, J., Rosenberg, D., and Puga, J. (1965). Report to VI PanAmerican Congress of Endocrinology, Mexico City, October.

Zañartu, J., Pupkin, M., Rosenberg, D., Puga, J. A., and Guerrero, R. (1967). Rev. méd. Chile, 95, 512 .

Zañartu, J., et al. (1968). Brit. med. Э., 2, 263.

Zussman, W. V., Forbes, D. A., and Carpenter, R. J. (1967). Amer. F. Obstet. Gynec., 99, 99.

\title{
Sleep and Wakefulness in Normal Human Adults
}

\author{
G. S. TUNE,* B.A., PH.D.
}

Brit. med.7., 1968, 2, 269-271

Considerable research has been devoted to the early changes in the human sleep/wakefulness pattern from the polycyclic regimen present in infancy (Gesell and Amatruda, 1945) to the more consolidated pattern usually evident in later childhood and adult years (Kleitman, 1963). Changes in the adult pattern have been studied less extensively; however, careful observations based on self-kept records (Lewis and Masterton, 1957) have shown that in unusual environments there are changes in both the duration and distribution of the sleep taken. Williams (1959), for example, reported that a brief stay at altitudes of over $10,000 \mathrm{ft}$. $(3,050 \mathrm{~m}$.) was sufficient to prolong the duration of sleep significantly in some subjects. Living in polar or subpolar regions had a rather different effect in that the duration of sleep was fairly constant, but it was taken at almost any hour of the day rather than during the customary hours of sleep at night-time (Lewis, 1961 ; Lewis and Masterton, 1957 ; Ross, 1962).

- Medical Research Council, Unit for Research on Occupational Aspects of Ageing, University of Liverpool.
More recent work has suggested that occupational stress may enforce a shortened duration of sleep, particularly in hospital medical staff (Masterton, 1965a, 1965b), to such an extent that a "sleep debt" was accumulated which was paid off during holiday periods. This was also found to be true of students, schoolchildren, and office workers (Masterton, 1965b).

In all of these studies and others (McGhie and Russell, 1962) there was wide variation between individuals in both the duration of sleep taken and in its distribution over the 24 hours of the day. There has been some suggestion that this may be due to personal factors such as age and sex. Best and Taylor (1952) stated that older people needed or took less sleep than younger people. This has been questioned, however (Tiller, 1964). It has also been shown that females claimed to get less satisfactory sleep than males (McGhie and Russell, 1962). The present research was undertaken in order to examine the age and sex differences in the adult sleep/wakefulness pattern in greater detail.

MEDICAL RESEARCH COUNCIL, UNIT FOR RESEARCH ON OCCUPATIONAL ASPECTS OF AGEING

\section{SLEEP CHART}

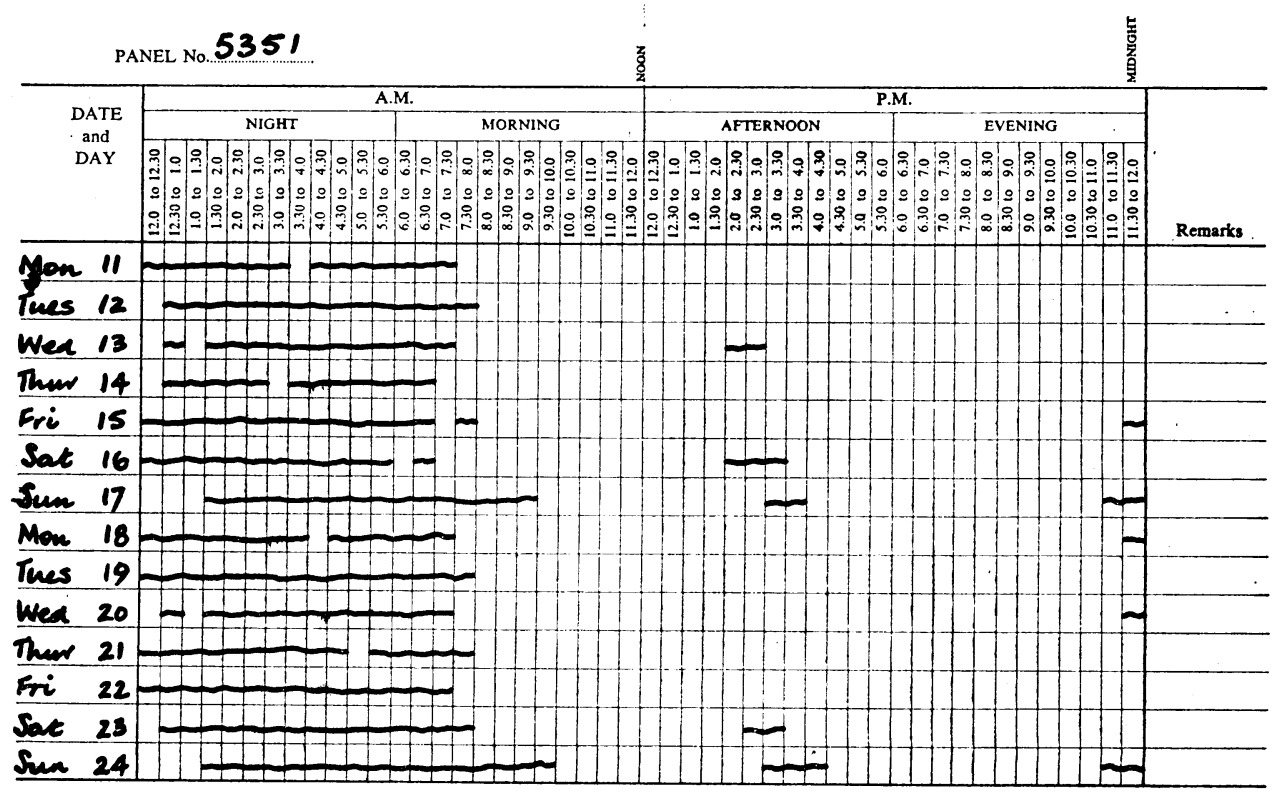

PLEASE PLACE A LINE IN EACH HALF-HOUR PERIOD DURING WHKY YOU SLEPT

FIG. 1.-Sleep chart used in the study. 